\title{
Comparative analysis of wild and cultivated Lathyrus L. spp. according to their primary and secondary metabolite contents
}

\author{
A.E. Solovyeva ${ }^{1}$, T.V. Shelenga ${ }^{1}$, A.L. Shavarda ${ }^{1,2,3}$, M.O. Burlyaeva ${ }^{1}$ \\ ${ }^{1}$ Federal Research Center the N.I. Vavilov All-Russian Institute of Plant Genetic Resources (VIR), St. Petersburg, Russia \\ ${ }^{2}$ St. Petersburg State University, St. Petersburg, Russia \\ ${ }^{3}$ V.L. Komarov Botanical Institute of the Russian Academy of Sciences, St. Petersburg, Russia \\ 凶e-mail: m.burlyaeva@vir.nw.ru
}

Species of the genus Lathyrus L. are known as forage and medicinal plants, widely used in traditional medicine and homeopathy. The content of protein, essential amino acids and carotene in their green biomass is higher than in other annual leguminous plants traditionally cultivated in Russia. Until now, the requirements for the crop's quality were reduced to a high content of protein and dry matter in seeds and herbage. In-depth biochemical analysis of accessions from the collection of plant genetic resources will significantly improve selection of source materials for breeding. Such tasks can be solved using gas chromatography with mass spectrometry in plant diversity studies. In view of the above, our goal was to analyze organic acids, free amino acids and secondary metabolites in green biomass of Lathyrus to facilitate comprehensive assessment of its forage and pharmacological value. We analyzed 32 accessions of Lathyrus sativus L., L. tuberosus L., L. sylvestris L., L. vernus (L.) Bernh., L. latifolius L. and L. linifolius (Reichard) Bassler from the collection of the Vavilov Institute (VIR). The studied Lathyrus accessions had significant interspecific and intraspecific variability both in the composition (presence) and number of the identified compounds. The analysis of plants across different years confirmed that biochemical parameters depended on weather conditions. The colder and drier conditions of 2012 contributed to the accumulation of organic acids (mean: $890 \mathrm{mg} / 100 \mathrm{~g}$ ), free amino acids (mean: $201.59 \mathrm{mg} / 100 \mathrm{~g}$ ), and secondary metabolites (mean: $84.14 \mathrm{mg} / 100 \mathrm{~g}$ ). The range of variability for organic acids ranged from 140 to 2140 , for free amino acids from 11.8 to 610 , and for secondary metabolites from 4.4 to $224.6 \mathrm{mg} / 100 \mathrm{~g}$. Grass pea accessions with high organic acid, free amino acid and secondary metabolite contents were identified: k-900 (Colombia) for organic acids (2140, 610 and 178 mg/100 g); k-51 (Georgia) and k-959 (Afghanistan) for free amino acids (401.29 and $540.63 \mathrm{mg} / 100 \mathrm{~g}$ ); k-893 (Eritrea) for secondary metabolites (199.39 mg/100 g), etc. They can serve as source material for the development of cultivars for different uses (forage and medicinal). Key words: Lathyrus L.; wild species; varieties; green mass; gas chromatography; genetic resource; polymorphism of characters.

For citation: Solovyeva A.E., Shelenga T.V., Shavarda A.L., Burlyaeva M.O. Comparative analysis of wild and cultivated Lathyrus L. spp. according to their primary and secondary metabolite contents. Vavilovskii Zhurnal Genetiki i Selektsii =Vavilov Journal of Genetics and Breeding. 2019;23(6):667-674. DOI 10.18699/VJ19.539

\section{Сравнительный анализ диких и культурных видов чины (Lathyrus L.) по содержанию веществ первичного и вторичного метаболизма}

\author{
А.Е. Сомовьева ${ }^{1}$, Т.В. Шеленга ${ }^{1}$, А.А. Шаварда ${ }^{1,2,3}$, М.О. Бурцяева ${ }^{1} \otimes$ \\ 1 Федеральный исследовательский центр Всероссийский институт генетических ресурсов растений им. Н.И. Вавилова (ВИР), \\ Санкт-Петербург, Россия \\ ${ }^{2}$ Санкт-Петербургский государственный университет, Санкт-Петербург, Россия \\ ${ }^{3}$ Ботанический институт им. В.Л. Комарова Российской академии наук, Санкт-Петербург, Россия \\ 凶e-mail: m.burlyaeva@vir.nw.ru
}

\begin{abstract}
Виды рода Lathyrus L. известны как кормовые и лекарственные растения, используемые в народной медицине и гомеопатии. Содержание белка, незаменимых аминокислот и каротина в зеленой массе чины выше, чем у других однолетних зернобобовых растений, традиционно культивируемых в России. До настоящего времени требования к качеству культуры сводились к высокому содержанию белка и сухого вещества в семенах и вегетативной массе. Углубленный биохимический анализ образцов из коллекции генетических ресурсов растений существенно улучшит отбор исходного материала для селекции. Изучение растительных ресурсов с использованием метода газовой хроматографии с масс-спектрометрией позволяет решить подобные задачи. В связи с вышесказанным нашей целью было исследование органических кислот, свободных аминокислот и соединений вторичного метаболизма в зеленой массе чины для всесторонней оценки ее кормовой и фармакологической ценности. Анализировали 32 образца Lathyrus sativus L., L. tuberosus L., L. sylvestris L., L. vernus (L.) Bernh., L. latifolius L., L. linifolius (Reichard) Bassler из коллекции Всероссийского института генетических ресурсов рас-
\end{abstract}




\begin{abstract}
тений им. Н.И. Вавилова. Изученные образцы Lathyrus обладали значительной межвидовой и внутривидовой изменчивостью как по составу (наличию), так и по количеству идентифицированных веществ. Анализ растений в разные годы подтвердил зависимость биохимических показателей от погодных условий. Более холодные и сухие условия 2012 г. способствовали накоплению органических кислот (среднее - 890 мг/100 г), свободных аминокислот (среднее - 201.59 мг/100 г) и соединений вторичного метаболизма (среднее - 84.14 мг/100 г). Диапазон изменчивости органических кислот составил от 140 до 2140, свободных аминокислот - от 11.8 до 610, соединений вторичного метаболизма - от 4.4 до 224.6 мг/100 г. Выделены образцы чины посевной: с повышенным содержанием органических кислот, свободных аминокислот и соединений вторичного метаболизма к-900 (Колумбия) (2140, 610 и 178 мг/100 г), свободных аминокислот - к-51 (Грузия) и к-959 (Афганистан) (401.29 и 540.63 мг/100 г), соединений вторичного метаболизма - к-893 (Эритрея) (199.39 мг/100 г) и другие, которые могут служить исходным материалом для создания сортов разного направления использования: кормового и лекарственного.
\end{abstract}

Ключевые слова: Lathyrus L.; дикие виды; сорта; зеленая масса; газовая хроматография; генетические ресурсы; полиморфизм признаков.

\section{Introduction}

Researching the chemical composition of cultivated plants and their wild relatives is of crucial importance in both theoretical and practical contexts. Still vital is the question of seeking new plants that may serve as sources of bioactive compounds with remedial properties, and introducing them into agricultural practice. Lathyrus sativus L., L. pratensis L. and L. tuberosus L. have been most comprehensively studied with regard to their chemical composition and pharmacological characteristics. Biological activity of several chemical components has been analyzed in L. sylvestris L., L. vernus (L.) Bernh. and L. niger (L.) Bernh. Wide pharmacological demand for peavines is induced by their macro- and microelement composition as well as the presence of flavonoids and a complex set of essential amino acids (Plant Resources of the USSR, 1987, 2011; Zaichikova, 2002a, b). Lathyrus spp. are also known as forage plants, outstanding for their high protein content in seed and herbage (Pavlova, 2001; Burlyaeva et al., 2012).

When peavine cultivars are developed, primary attention is given to yield, resistance to biotic and abiotic environmental factors, and the traits that secure their value as animal feed. Of late, the in-depth biochemical analysis has been used to solve numerous problems, such as the assessment of cultivar specificity of seeds (Smolikova et al., 2015; Loskutov et al., 2016) and study of the effects of domestication processes and environmental stressors (Konarev et al., 2015; Puzanskiy et al., 2015), etc. Modern gas chromatography (GC) with mass selective detection (MSD) techniques make it possible to examine plant biochemical composition varying with time and growing conditions (Konarev et al., 2015; Puzanskiy et al., 2015).

The collection of Lathyrus spp. at VIR contains 2055 accessions; they belong to more than 50 species. Widely represented in the collection are landraces, cultivars bred domestically and abroad, and their wild relatives from European Russia, Europe, Asia, Africa, Australia, etc. For many years, accessions from the collection have been studied mostly for protein content in seed and herbage. No in-depth biochemical research has been undertaken until now to study wild relatives and cultivated forms of Lathyrus spp. We have also failed to find any scientific publications where variations in the biochemical composition of peavine green biomass were analyzed under different weather conditions.

When peavine cultivars are developed for feed, food and medicinal purposes, emphasis is placed by breeders on raising the content of nutrients and secondary metabolites in green biomass. In view of this, the goal of this research was to study the biochemical composition of Lathyrus green biomass for comprehensive assessment of its forage and pharmacological value. Research objectives included analyzing inter- and intraspecific polymorphism of biochemical characters in Lathyrus spp., assessing the effect of weather conditions on the analyzed parameters, and identifying most promising accessions for breeding practice.

\section{Materials and methods}

The experiment employed 32 accessions of six Lathyrus species from the VIR collection: grass pea (L. sativus), flat pea (L. sylvestris), spring pea (L. vernus), heath pea (L. linifolius), everlasting pea (L. latifolius), and tuberous pea (L. tuberosus), grown in 2012 and 2013 in fields of the Pushkin Laboratories of VIR in the vicinities of St. Petersburg. Plants were grown on one-meter plots $\left(1 \mathrm{~m}^{2}\right)$ in two replications (the plots were situated in one and the same place), on naturally irrigated soddy-podzolic soil. Standard agricultural practices for row crops adopted at VIR (Vishnyakova et al., 2010) were applied. Weather conditions in the growing seasons were contrasting. In 2012 , the total of active temperatures was $1885.0^{\circ} \mathrm{C}$, with total precipitation of $340.7 \mathrm{~mm}$. In 2013 , the total of active temperatures was observed to rise to $2474.3^{\circ} \mathrm{C}$, with total precipitation going up to reach $646.4 \mathrm{~mm}$.

The plants were harvested in the early pod ripening phase. Fresh green biomass of plants was analyzed (five plants from each accession: stems, leaves and pods; in three analytical replications).

A sample of $10 \mathrm{~g}$ was weighed, homogenized with an adequate amount of ethanol, and infused for 30 days at $5-6{ }^{\circ} \mathrm{C}$. The extract $(200 \mu \mathrm{L})$ was vaporized to dry residues on a CentriVapConcentrator (Labconco, USA). The solid residue was silylated with bis(trimethylsilyl)trifluoroacetamide. The silylated compounds were separated on an HP-5MS capillary column (5\% phenyl methylpolysiloxane; $30.0 \mathrm{~m}, 250.00 \mu \mathrm{m}$, $0.25 \mu \mathrm{m})$ using the Agilent 6850 chromatography system with a quadrupole mass spectrometry detector Agilent 5975B VL MSD (Agilent Technologies, USA). Conditions of chromatographic analysis: helium flow rate through the column $1.5 \mathrm{~mL} / \mathrm{min}$, column heating program $+70{ }^{\circ} \mathrm{C}$ to $+320{ }^{\circ} \mathrm{C}$ with the heating rate $4{ }^{\circ} \mathrm{C} / \mathrm{min}$, MSD temperature $+250{ }^{\circ} \mathrm{C}$, injector temperature $+300{ }^{\circ} \mathrm{C}$, sample volume $1 \mu \mathrm{L}$, internal standard: tricosane in pyridine $(1 \mu \mathrm{g} / \mu \mathrm{L})$. 
The spectra were processed using UniChrom and AMDIS software, NIST 2010 mass spectra libraries, and Science parks of the St. Petersburg State University and the Komarov Botanical Institute. The results were evaluated with MS Excel 2007 and Statistica 7.0 programs. The effect of environmental conditions on the expression of biochemical characters was assessed using one-way analysis of variance (ANOVA) with Fisher's LSD-test. The effect size of the factor's influence $\left(\eta^{2}, \%\right)$ according to Fisher was calculated by Equation (1) (Ivanter, Korosov, 2003):

$$
\eta^{2}=\frac{\mathrm{SS}_{\text {factor }}}{\mathrm{SS}_{\text {total }}} \times 100 \%,
$$

where $\eta^{2}, \%$ is the effect size of the factor influence; $\mathrm{SS}_{\text {factor }}$ is the sum of squared deviations for the factor; $\mathrm{SS}_{\text {total }}$ is the total sum of squared deviations.

\section{Results}

The biochemical composition analysis of the Lathyrus green biomass samples revealed about 300 components. This paper discusses part of the data obtained (Table 1, Suppl. material $\left.1^{1}\right)$.

Organic acids. In 2012, the content of organic acids in the green biomass samples of Lathyrus averaged $844.72 \mathrm{mg} /$ $100 \mathrm{~g}$; depending on the genotype, this parameter varied from 136.27 to $2137.37 \mathrm{mg} / 100 \mathrm{~g}$. In 2013 , the acid content went down to $333.77 \mathrm{mg} / 100 \mathrm{~g}$, and different accessions varied within $215.37-544.24 \mathrm{mg} / 100 \mathrm{~g}$ (Fig. 1). For grass pea accessions, the mean content of organic acids in 2012 was $890 \mathrm{mg} /$ $100 \mathrm{~g}$, with the range of variation from 300 to $2140 \mathrm{mg} / 100 \mathrm{~g}$. In 2013 , a decrease to $3120 \mathrm{mg} / 100 \mathrm{~g}$ was observed in the mean values, and the range narrowed to $220-430 \mathrm{mg} / 100 \mathrm{~g}$. In the flat pea group, the mean content of organic acids was $590 \mathrm{mg} / 100 \mathrm{~g}$ in 2012, and $480 \mathrm{mg} / 100 \mathrm{~g}$ in 2013. For L. sylvestris, this parameter was relatively stable in different years, unlike L. sativus, which demonstrated a drop of the organic acid content to $570 \mathrm{mg} / 100 \mathrm{~g}$ in 2013. The organic acid contents in heath, everlasting, and spring pea accessions were somewhat higher: 610,670 , and $640 \mathrm{mg} / 100 \mathrm{~g}$, respectively.

The lowest level of organic acids was recorded for tuberous pea accessions $(140 \mathrm{mg} / 100 \mathrm{~g})$. The highest acid content in 2012 was observed in grass pea accession k-900 (Colombia): $2140 \mathrm{mg} / 100 \mathrm{~g}$; and in 2013, in flat pea accession k-591293 (Germany): $540 \mathrm{mg} / 100 \mathrm{~g}$.

Organic acids were represented mostly by malic (Krebs cycle) and threonic (ascorbic acid oxidation product) acids; their respective contents were 156.22 and $120.52 \mathrm{mg} / 100 \mathrm{~g}$. Glyceric and citric acids ranked next: their contents were 90.63 and $61.32 \mathrm{mg} / 100 \mathrm{~g}$, respectively. Dehydroabietic, phosphoric, oxalic, lactic, and fumaric acids respectively averaged 30.42 , $27.14,25.90,14.61$, and $10.65 \mathrm{mg} / 100 \mathrm{~g}$. The contents of succinic, mesoxalic, quinic, erythronic and gluconic acids did not exceed $10 \mathrm{mg} / 100 \mathrm{~g}(9.17,6.87,6.58,6.34$, and 5.82, respectively). Respective amounts of tartaric, ribonic and pipecolic acids were 2.77, 2.04, and 1.85. Accumulation of other acids (benzoic, nicotinic, maleic, 4-hydroxybenzoic, azelaic, saccharic, protocatechuic, shikimic, galacturonic, caffeic, sinapic, abietic and neochlorogenic) never exceeded

\footnotetext{
${ }^{1}$ Supplementary Materials 1-2 are available in the online version of the paper: http://www.bionet.nsc.ru/vogis/download/pict-2019-23/appx12.pdf
}

Table 1. The contents of amino acids, organic acids, and secondary metabolites in the green biomass of some Lathyrus species (mg/100 $\mathrm{g}$ wet weight)

\begin{tabular}{|c|c|c|c|}
\hline Species & Organic acids & Amino acids & $\begin{array}{l}\text { Secondary } \\
\text { metabolites }\end{array}$ \\
\hline \multirow[t]{2}{*}{ L. sativus } & $610.0 \pm 64.0^{*}$ & $208.6 \pm 16.8$ & $59.2 \pm 8.0$ \\
\hline & $220.0-2140.0^{* *}$ & $41.0-610.0$ & 4.4-199.4 \\
\hline \multirow[t]{2}{*}{ L. sylvestris } & $520.0 \pm 84.6$ & $205.1 \pm 45.9$ & $43.1 \pm 14.3$ \\
\hline & $340.0-830.0$ & $67.5-340.3$ & $15.2-79.8$ \\
\hline \multirow[t]{2}{*}{ L. vernus } & $640.0 \pm 94.9$ & $28.0 \pm 2.9$ & $28.1 \pm 6.9$ \\
\hline & $540.0-730.0$ & $25.1-31.0$ & $21.8-35.7$ \\
\hline \multirow[t]{2}{*}{ L. linifolius } & $830.0 \pm 89.5$ & $11.8 \pm 6.2$ & $71.6 \pm 29.7$ \\
\hline & $250.0-1050.0$ & $3.1-14.8$ & $32.2-100.1$ \\
\hline \multirow[t]{2}{*}{ L. latifolius } & $670.0 \pm 75.6$ & $136.3 \pm 38.3$ & $132.4 \pm 52.1$ \\
\hline & $100.0-850.0$ & $42.3-157.9$ & $81.5-224.6$ \\
\hline \multirow[t]{2}{*}{ L. tuberosus } & $140.0 \pm 98.9$ & $72.9 \pm 25.3$ & $6.4 \pm 9.8$ \\
\hline & $2.0-380.0$ & $24.8-95.4$ & $1.1-19.5$ \\
\hline
\end{tabular}

* Arithmetic mean \pm standard error of the mean;

** Range (min-max).

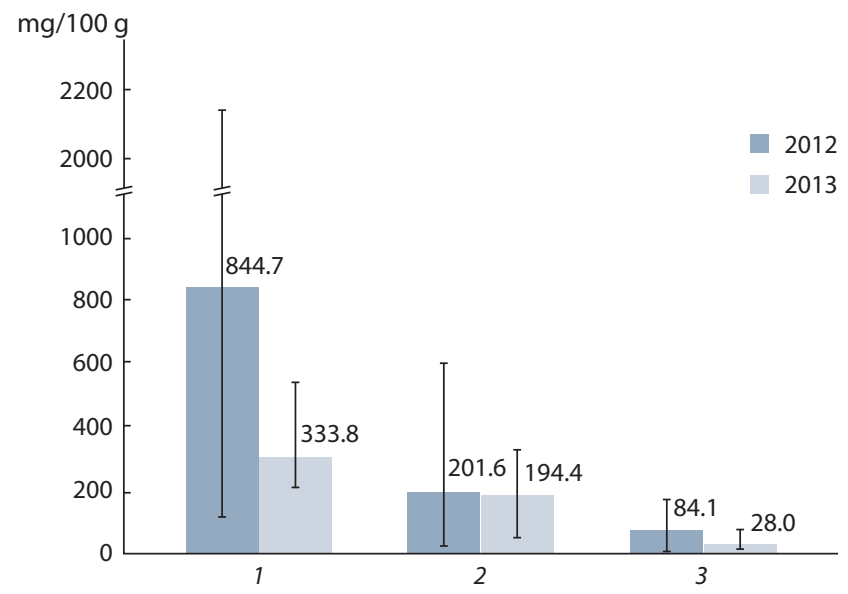

Fig. 1. The contents of organic acids, free amino acids, and phenolic compounds in the green biomass of Lathyrus L. in different years of cultivation (mean values, min-max, $\mathrm{mg} / 100 \mathrm{~g}$ wet weight).

1 - organic acids; 2 - free amino acids; 3 - secondary metabolites.

$0.7 \mathrm{mg} / 100 \mathrm{~g}$, while the respective amounts of galacturonic and saccharic acids were 0.29 and $0.06 \mathrm{mg} / 100 \mathrm{~g}$.

Amino acids. The green biomass of Lathyrus accessions was found to contain 20 free amino acids, including eight essential ones (see Suppl. material 1). The mean content of free amino acids in 2012 was $201.59 \mathrm{mg} / 100 \mathrm{~g}$ (see Fig. 1); the variation being from 11.75 to $610.00 \mathrm{mg} / 100 \mathrm{~g}$. In 2013, the amino acid content was slightly lower (194.42 mg/100 g), while the range of variability for this character in different genotypes was within the limits from 40.97 to $340.30 \mathrm{mg} / 100 \mathrm{~g}$. In 2012, the highest free amino acid contents were registered in grass pea accessions $(230.16 \mathrm{mg} / 100 \mathrm{~g})$, and the lowest in heath pea $(11.75 \mathrm{mg} / 100 \mathrm{~g})$. The same parameters measured 
in other species were as follows: $114.93 \mathrm{mg} / 100 \mathrm{~g}$ in flat pea, 136.28 in everlasting pea, 72.90 in spring pea, and 28.02 in tuberous pea. In 2013, the mean amino acid content in the green biomass of flat pea was higher $(265.22 \mathrm{mg} / 100 \mathrm{~g})$. Grass pea, however, showed the opposite tendency, as this parameter dropped to $185.92 \mathrm{mg} / 100 \mathrm{~g}$ in 2013 . Other Lathyrus groups showed no significant variations across the two years.

Secondary metabolic compounds. One of the key indicators that reflect antioxidant activity and resistance to the impact of environmental stressors is the content of secondary metabolites, including phenol-containing compounds. The effect of secondary metabolites is directly connected with their concentrations; in this regard, their quantitative analysis is no less important than qualitative one (Spanou et al., 2010).

In the tested green biomass of Lathyrus accessions, secondary metabolites were represented by free phenolcarboxylic (PC) acids (mean content 52.52), quinones (0.38), flavonoids (3.49), phenylpropanoids (0.69), and iridoids (0.11), including the identified $\alpha$-tocopherol (2.14 mg/100 g) (see Suppl. material 1). The mean content of secondary metabolites in the green biomass of Lathyrus accessions in 2012 was $84.14 \mathrm{mg} / 100 \mathrm{~g}$ (from 4.45 to 199.39) (see Fig. 1). In 2013, the mean decreased to $28.04 \mathrm{mg} / 100 \mathrm{~g}$ (from 13.23 to 53.45 ). In 2012, the highest contents of secondary metabolites were recorded in everlasting pea accessions (132.44 mg/100 g), and the lowest in tuberous pea $(6.42 \mathrm{mg} / 100 \mathrm{~g})$. In the green biomass of grass pea, flat pea, heath pea, and spring pea, the mean values of secondary metabolites (89.32, 78.01, 71.59, and $28.74 \mathrm{mg} / 100 \mathrm{~g}$, respectively) were lower than in everlasting pea. In 2013, the mean secondary metabolite contents in grass pea and flat pea dropped to 29.03 and $19.80 \mathrm{mg} / 100 \mathrm{~g}$, respectively.

One-way ANOVA was used to ascertain the significance of the impact of weather conditions on the content of the analyzed biochemical characters. The analysis allowed identification of 79 compounds significantly affected by growing conditions (Table 2), including total organic acids and secondary metabolites. The effect size (percentage) for the influence of environmental conditions $\left(\eta^{2}\right)$ on the content of organic acids was $67.9 \%$ for lactic acid, $39.0 \%$ for glyceric acid, $37.5 \%$ for threonic acid, $33.4 \%$ for fumaric acid, and $34.5 \%$ for the total organic acid content (Fig. 2). Of free amino acids, including aminoalcohols and amines, the greatest weather impact was registered for the contents of ethanolamine $\left(\eta^{2}=72.9 \%\right)$, leucine (51.6), GABA (48.9), methionine (47.9), putrescine (43.1), adenosine (41.2), glycine (34.6), asparaginic acid (29.9), and asparagine (29.0). For weather impact on the variability of secondary metabolites, the highest effect size was recorded for quercetin $\left(\eta^{2}=39.8 \%\right)$ and dehydroabietic acid (30.4). For the total content of secondary metabolites, it was $26.1 \%$.

Despite the large number of compounds identified in the green biomass of Lathyrus spp., only quantitative indicators in some of them accounted for statistically significant differences between wild species: catechin $(\mathrm{F}(5 ; 54)=10.47$, $p=0.0000), \alpha$-alanine $(\mathrm{F}(5 ; 54)=2.52, p=0.039)$, asparagine $(\mathrm{F}(5 ; 54)=3.32, p=0.011)$, glycine $(\mathrm{F}(5 ; 54)=3.25$, $p=0.012)$, and shikimic acid $(\mathrm{F}(5 ; 54)=31.66, p=0.0000)$. Asparagine, glycine, $\alpha$-alanine and catechin contents were the highest in flat pea (L. sylvestris), and shikimic acid content, in everlasting pea (L. latifolius) (Suppl. material 2).
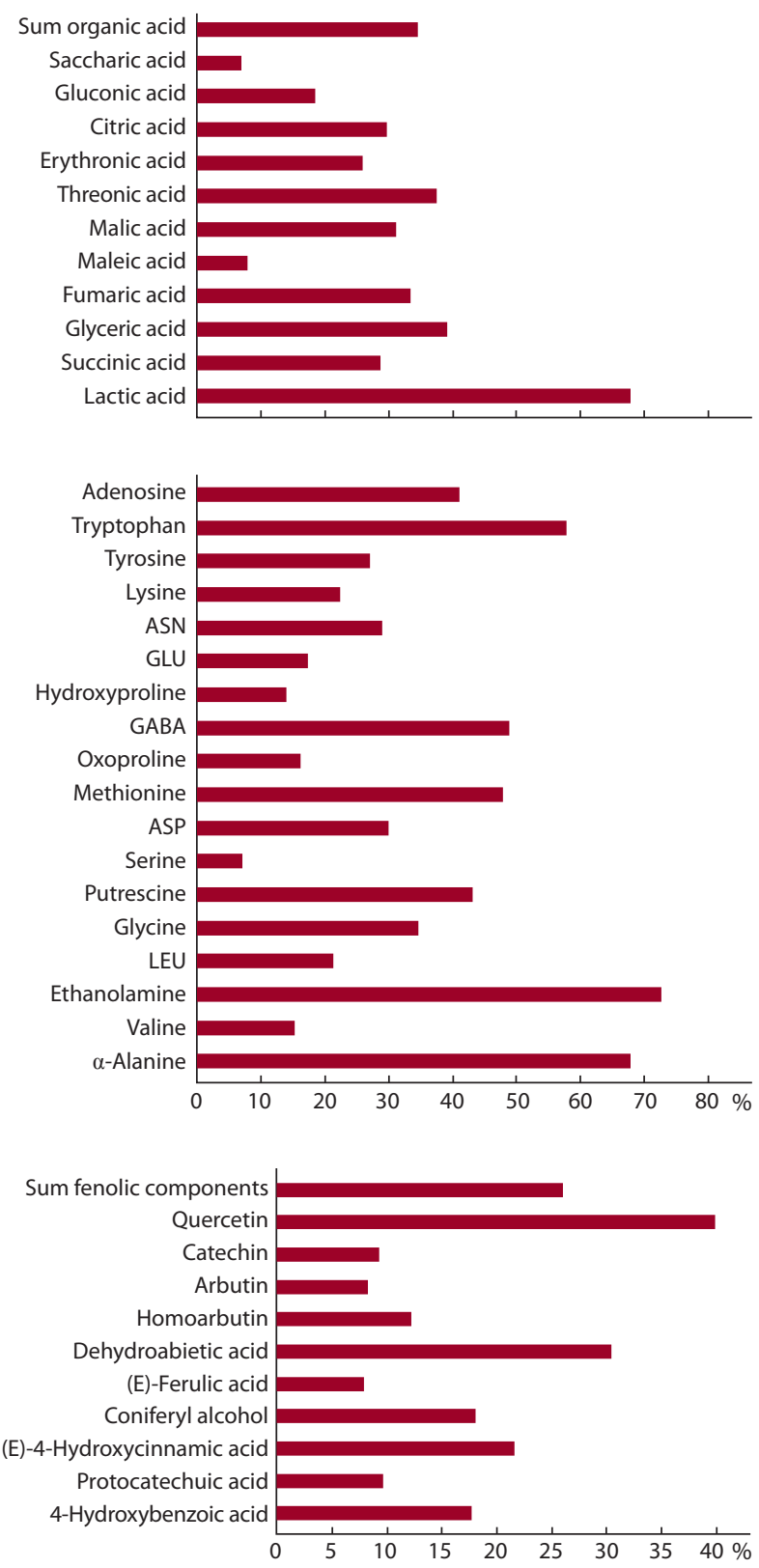

Fig. 2. The effect size $\left(n^{2}, \%\right)$ for the influence of weather conditions on the variability of biochemical characteristics.

\section{Discussion}

The studied Lathyrus accessions demonstrated broad polymorphism in the biochemical composition of green biomass. Significant interspecific and intraspecific variability was observed both in the composition (presence) and the amount of the identified compounds. The highest content of organic acids was found in L. sativus: $2140 \mathrm{mg} / 100 \mathrm{~g}$ (k-900, Colombia); free amino acids in L. sylvestris: $265.22 \mathrm{mg} / 100 \mathrm{~g}(\mathrm{k}-2017$, Germany); and total secondary metabolites in L. latifolius: $132.44 \mathrm{mg} / 100 \mathrm{~g}$ (i-594176, Germany). The analysis showed 
Table 2. The results of one-way analysis of variance (ANOVA) to identify the association between the variability of biochemical parameters and weather conditions in the year of reproduction

\begin{tabular}{|c|c|c|c|c|c|c|c|c|c|c|c|c|c|c|c|c|}
\hline \multirow[t]{2}{*}{ Effect } & \multirow[t]{2}{*}{ df } & \multicolumn{3}{|l|}{ Lactic acid } & \multicolumn{3}{|c|}{ Succinic acid } & \multicolumn{3}{|c|}{ Glyceric acid } & \multicolumn{3}{|c|}{ Fumaric acid } & \multicolumn{3}{|c|}{ Maleic acid } \\
\hline & & SS & $\mathrm{F}$ & $p$ & SS & $\mathrm{F}$ & $p$ & SS & $\mathrm{F}$ & $p$ & SS & $\mathrm{F}$ & $p$ & SS & $\mathrm{F}$ & $p$ \\
\hline Year & 1 & 6515.0 & 122.9 & 0.00 & 1194.8 & 23.1 & 0.00 & 249259.9 & 37.0 & 0.00 & 5736.3 & 29.1 & 0.00 & 18.8 & 4.9 & 0.03 \\
\hline Error & 58 & 3074.5 & & & 3004.4 & & & 390349.6 & & & 11439.2 & & & 222.2 & & \\
\hline Total & 59 & 9589.5 & & & 4199.2 & & & 639609.5 & & & 17175.5 & & & 241.0 & & \\
\hline$\eta^{2}$ & & 67.9 & & & 28.5 & & & 39.0 & & & 33.4 & & & 7.8 & & \\
\hline \multirow[t]{2}{*}{ Effect } & \multicolumn{4}{|c|}{ If Malic acid } & \multicolumn{3}{|c|}{ Threonic acid } & \multicolumn{3}{|c|}{ Erythronic acid } & \multicolumn{3}{|l|}{ Citric acid } & \multicolumn{3}{|c|}{ Saccharic acid } \\
\hline & & SS & $\mathrm{F}$ & $p$ & SS & $\mathrm{F}$ & $p$ & SS & $\mathrm{F}$ & $p$ & SS & $\mathrm{F}$ & $p$ & SS & $\mathrm{F}$ & $p$ \\
\hline Year & 1 & 319326.9 & 26.2 & 0.00 & 340838.3 & 34.8 & 0.00 & 1664.9 & 20.2 & 0.00 & 92898.4 & 24.4 & 0.00 & 0.3 & 4.1 & 0.04 \\
\hline Error & 58 & 705960.5 & & & 567394.8 & & & 4780.5 & & & 221251.6 & & & 3.9 & & \\
\hline Total & 59 & 1025287.3 & & & 908233.0 & & & 6445.4 & & & 314150.1 & & & 4.2 & & \\
\hline$\eta^{2}$ & & 31.1 & & & 37.5 & & & 25.8 & & & 29.6 & & & 6.7 & & \\
\hline \multirow[t]{2}{*}{ Effect } & df & \multicolumn{3}{|c|}{ Gluconic acid } & \multicolumn{3}{|c|}{ Total organic acid } & \multicolumn{3}{|c|}{ 4-Hydroxybenzoic acid } & \multicolumn{3}{|c|}{ Protocatechuic acid } & \multicolumn{3}{|c|}{$\begin{array}{l}\text { (E)-4-Hydroxycinnamic } \\
\text { acid }\end{array}$} \\
\hline & & SS & $\mathrm{F}$ & $p$ & SS & $\mathrm{F}$ & $p$ & SS & $\mathrm{F}$ & $p$ & SS & $\mathrm{F}$ & $p$ & SS & $\mathrm{F}$ & $p$ \\
\hline Year & 1 & 1083.8 & 13.0 & 0.00 & 3624902.5 & 30.6 & 0.00 & 0.2 & 12.4 & 0.00 & 0.2 & 6.2 & 0.02 & 853.8 & 15.9 & 0.00 \\
\hline Error & 58 & 4819.6 & & & 6880021.4 & & & 0.7 & & & 1.4 & & & 3119.8 & & \\
\hline Total & 59 & 5903.3 & & & 10504923. & & & 0.9 & & & 1.6 & & & 3973.6 & & \\
\hline$\eta^{2}$ & & 18.4 & & & 34.5 & & & 17.6 & & & 9.6 & & & 21.5 & & \\
\hline \multirow[t]{2}{*}{ Effect } & \multirow[t]{2}{*}{ df } & Coniferol & & & \multicolumn{3}{|c|}{ (E)-Ferulic acid } & \multicolumn{3}{|l|}{ Catechin } & Arbutin & & & Querc & & \\
\hline & & SS & $\mathrm{F}$ & $p$ & SS & $\mathrm{F}$ & $p$ & SS & $\mathrm{F}$ & $p$ & SS & $\mathrm{F}$ & $p$ & SS & $\mathrm{F}$ & $p$ \\
\hline Year & 1 & 32.9 & 12.7 & 0.00 & 134.5 & 4.9 & 0.03 & 3.3 & 5.9 & 0.02 & 0.9 & 5.1 & 0.03 & 1.1 & 38.3 & 0.00 \\
\hline Error & 58 & 149.9 & & & 1576.1 & & & 32.8 & & & 10.6 & & & 1.6 & & \\
\hline Total & 59 & 182.9 & & & 1710.6 & & & 36.1 & & & 11.5 & & & 2.7 & & \\
\hline$\eta^{2}$ & & 18.0 & & & 7.9 & & & 9.2 & & & 8.1 & & & 39.8 & & \\
\hline Effect & df & Quinic acic & & & Homoarbu & & & Dehydroa & bietic a & icid & $\begin{array}{l}\text { Total phe } \\
\text { compoun }\end{array}$ & $\begin{array}{l}\text { nolic } \\
\text { dds }\end{array}$ & & Ethanc & ine & \\
\hline & & SS & $\mathrm{F}$ & $p$ & SS & $\mathrm{F}$ & $p$ & SS & $\mathrm{F}$ & $p$ & SS & $\mathrm{F}$ & $p$ & SS & $\mathrm{F}$ & $p$ \\
\hline Year & 1 & 2414.1 & 96.8 & 0.00 & 1.2 & 8.0 & 0.01 & 48067.3 & 25.3 & 0.00 & 45145.9 & 20.5 & 0.00 & 16.3 & 156.3 & 0.00 \\
\hline Error & 58 & 1447.1 & & & 8.4 & & & 110250.0 & & & 127578.5 & & & 6.0 & & \\
\hline Total & 59 & 3861.1 & & & 9.6 & & & 158317.3 & & & 172724.4 & & & 22.3 & & \\
\hline$\eta^{2}$ & & 62.5 & & & 12.1 & & & 30.4 & & & 26.1 & & & 72.9 & & \\
\hline Effect & $\mathrm{df}$ & $\alpha$-Alanine & & & Valine & & & Serine & & & Leucine & & & Adeno & & \\
\hline & & SS & $\mathrm{F}$ & $p$ & SS & $\mathrm{F}$ & $p$ & SS & $\mathrm{F}$ & $p$ & SS & $\mathrm{F}$ & $p$ & SS & $\mathrm{F}$ & $p$ \\
\hline Year & 1 & 937.3 & 9.8 & 0.00 & 146.9 & 10.4 & 0.00 & 2088.8 & 4.4 & 0.04 & 62.5 & 15.7 & 0.00 & 103.6 & 40.7 & 0.00 \\
\hline Error & 58 & 5546.7 & & & 817.2 & & & 27385.9 & & & 231.1 & & & 147.7 & & \\
\hline Total & 59 & 6484.0 & & & 964.2 & & & 29474.7 & & & 293.6 & & & 251.3 & & \\
\hline$\eta^{2}$ & & 14.5 & & & 15.2 & & & 7.1 & & & 21.3 & & & 41.2 & & \\
\hline
\end{tabular}


Table 2. (End)

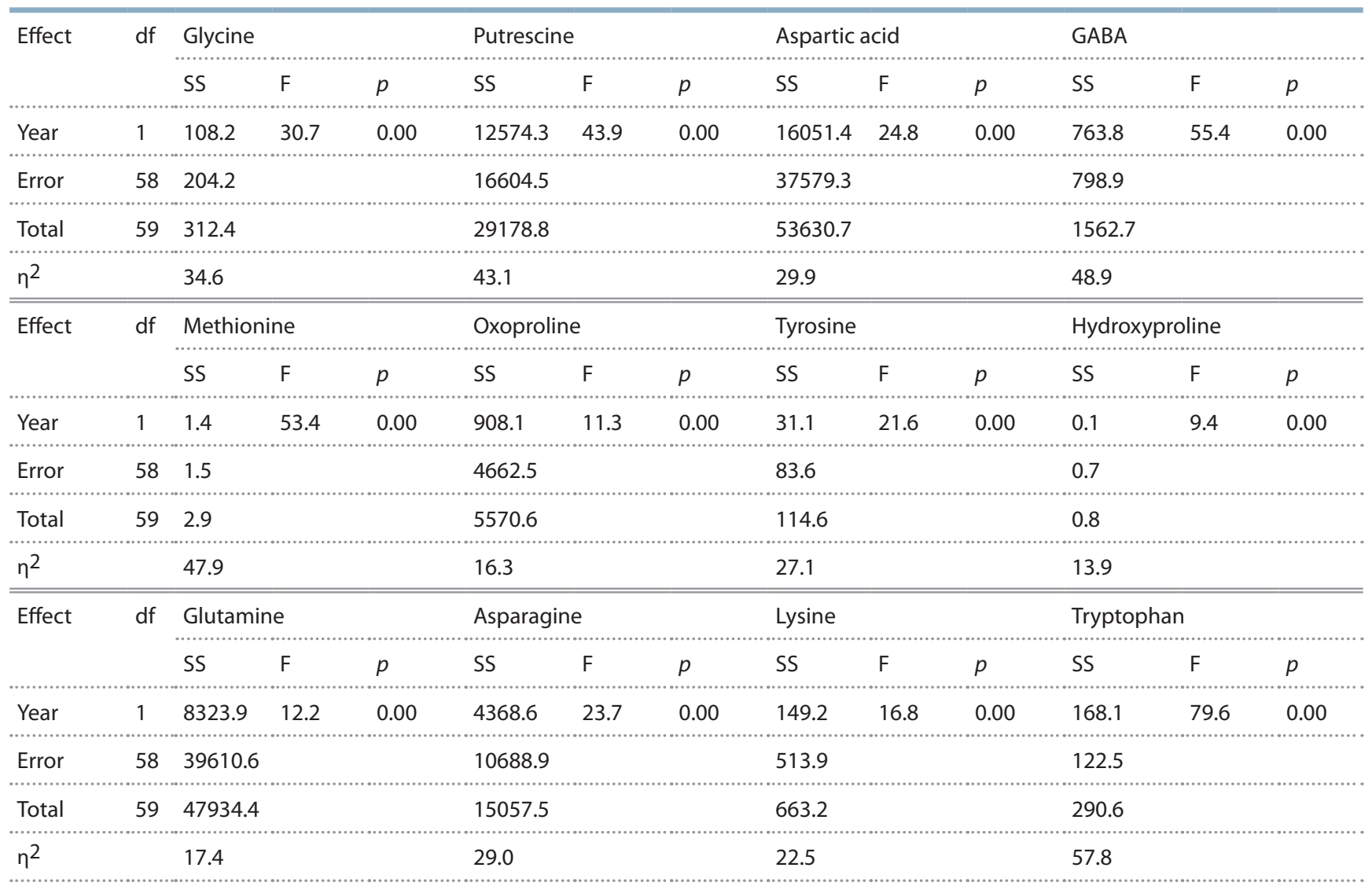

Note: SS - sum of squares; F - Fisher's criterion value; $p$ - level of significance; $\mathrm{df}$ - degrees of freedom; $\eta^{2}, \%$ - the effect size of the factor's influence; year, weather conditions.

sizeable variation of biochemical parameters under different weather conditions. The colder and drier season in 2012 was conducive to the accumulation of organic acids, amino acids, and secondary metabolites.

There is no published information on the content of organic acids in the green biomass of Lathyrus. The analyzed accessions contained mostly acids participating in cell respiration, ascorbic acid oxidation products (threonic acid), natural antiseptics and antioxidants (azelaic acid), and anti-stress factors of plant cells (pipecolic and maleic acids) (Yao et al., 1998; Mahmud et al., 2017). The highest contents of individual organic acids were found in the following grass pea accessions: malic acid in k-893 (Eritrea) and k-900 (Colombia) (495 and $505 \mathrm{mg} / 100 \mathrm{~g}$ ); threonic acid in k-900 (Colombia) (522 mg/ $100 \mathrm{~g})$; azelaic acid in k-275 (Azerbaijan) $(8.20 \mathrm{mg} / 100 \mathrm{~g})$; maleic acid in k-889 (Abyssinia) and k-34 (Russia) (8.78 and $8.92 \mathrm{mg} / 100 \mathrm{~g}$ ). The everlasting pea accession k-51 (Germany) showed a high content of pipecolic acid $(59.18 \mathrm{mg} / 100 \mathrm{~g})$.

Our data on the free amino acid content differ from those published by S.G. Zaichikova et al. (2001), who identified 18 amino acids in Lathyrus herbage, including 7 essential ones, plus histidine and arginine not detected by us. In addition to the above-mentioned free amino acids, our experiment revealed tryptophan, GABA, asparagine, glycine, etc. In the said publication by S.G. Zaichikova et al., the main amino acids in peavine green biomass were glutamine and histidine: they respectively accounted for 15 and $11.6 \%$ of the total amount of identified amino acids. E. Pastor-Cavada et al. (2010) identified 17 amino acids, including 9 essential ones, in Lathyrus seeds. Our research showed that the green biomass of Lathyrus spp. contained 20 amino acids (8 essential ones). The main amino acids in seeds were glutamic and aspartic acids, and in green biomass, according to our data, serine, glutamic and aspartic acids (16.4, 16.6, and $13.5 \%$ of the total amount of identified amino acids, respectively). The major essential amino acids were arginine, leucine, and lysine in seeds and threonine (much more abundant than other amino acids) in green biomass. We singled out the grass pea accession k-842 (Tajikistan) for its high content of glycine $(3.26 \mathrm{mg} / 100 \mathrm{~g})$, an indicator of resistance to environmental stressors (Loskutov et al., 2016).

According to published data, flavonoids are the main phenol-containing compounds in the Lathyrus green biomass, their amount reaching $50 \%$ of the total phenolic content. Our research has shown that the main components of phenolcontaining compounds are free PC acids: they possess the highest antioxidant capacity (Shetty et al., 2002). Extracts of grass pea and flat pea in relevant concentrations are known to produce stimulating effect on the phagocytic and antibacterial activity of human neutrophils, which is associated with the presence of free PC acids in them (Zaichikova, 2002a, b).

The qualitative and quantitative compositions of secondary metabolites identified by us differed from the data published by F. Sibul et al. (2016), because different research 
methods were applied. Sibul et al. used HPLC to identify a wide spectrum of hydroxybenzoic and hydroxycinnamic acids in Lathyrus leaves, as well as a high content of quinic acid $(30.4-35.0 \mathrm{mg} / 100 \mathrm{~g})$, with the total secondary metabolite content being $58.1 \mathrm{mg} / 100 \mathrm{~g}$ dry weight (DW). In our study, the total content of secondary metabolites was much higher $(246.85 \mathrm{mg} / 100 \mathrm{~g})$, with ferulic and quinic acids being the most abundant ( 40.63 and $28.30 \mathrm{mg} / 100 \mathrm{~g} \mathrm{DW}$ ). We managed to identify only four hydroxybenzoic acids (pyrogallol, 4-hydroxybenzoic, protocatechuic and benzoic acids) against six identified by F. Sibul et al. (2016). The content of protocatechuic acid in our experiment was somewhat lower than those reported by other researchers $(0.2$ and $0.9 \mathrm{mg} / 100 \mathrm{~g} \mathrm{DW})$. Of hydroxycinnamic acids, we identified ferulic, sinapic, and caffeic acids $(19.09,0.03$, and $2.09 \mathrm{mg} / 100 \mathrm{~g} \mathrm{DW})$, while our colleagues found ferulic, $p$-coumaric, and caffeic acids $(1.38,1.42$, and $1.02 \mathrm{mg} / 100 \mathrm{~g} \mathrm{DW})$. The content of ferulic acid in our accessions was much higher, and that of caffeic acid slightly lower than the values reported by scientists outside Russia. The content of chlorogenic acid was low in the accessions analyzed by us and in the plants tested by F. Sibul et al. (2016): $0.8 \mathrm{mg} / 100 \mathrm{~g}$ DW. The content of luteolin in our genotypes was lower than the same parameter reported by other authors (1.21 and $4 \mathrm{mg} / 100 \mathrm{~g} \mathrm{DW})$. Our accessions contained more catechin and quercetin $(0.95$ and 4.00) than the plants tested by F. Sibul et al. (2016): 0.04 and $1.60 \mathrm{mg} / 100 \mathrm{~g}$ DW. The levels of kaempferol were practically identical (1.78 and $1.60 \mathrm{mg} / 100 \mathrm{~g} \mathrm{DW}$, respectively), but the content of isorhamnetin in our Lathyrus accessions $(0.02 \mathrm{mg} / 100 \mathrm{~g} \mathrm{DW})$ was considerably lower than the value published by non-Russian researchers $(0.53 \mathrm{mg} / 100 \mathrm{~g} \mathrm{DW})$. F. Sibul et al. (2016) identified a wider spectrum of flavones and glycosides. We did not identify isoflavones, coumarins, or several glycosides. However, our research efforts yielded data on other secondary metabolites (hydroquinone, shikimic acid, and coniferol).

U.D. Chavan (1998) reported the total content of secondary metabolites in sea pea (L. maritimus L.), which was beyond the scope of our research; those levels varied from 0.5 to $3.0 \%$, being roughly close to our results $(0.3-0.9 \%)$.

We selected the grass pea accessions k-893 (Eritrea) and k-900 (Colombia) for their high content of secondary metabolites (199.39 and $177.82 \mathrm{mg} / 100 \mathrm{~g}$ ) as potential sources of resistance and pharmacological value.

Our research confirmed the impact of weather conditions (temperature and precipitation amount) on the accumulation of organic acids, free amino acids, and major secondary metabolites (Popov et al., 2016). The analysis helped us identify accessions with high contents of substances responsible for protection against adverse environmental factors (maleic and pipecolic acids, glycine, and the aggregate content of secondary metabolites) and compounds of value for pharmacology (azelaic acid), which hold promise in the development of new nutritious, resistant, or medicinal cultivars of Lathyrus.

\section{Conclusion}

Thus, our research has brought forth new data on the biochemical composition of peavine green biomass. Its results confirm that Lathyrus is a promising forage and medicinal crop with a potential for various branches of economy.

\section{References}

Burlyaeva M.O., Solovyeva A.E., Nikishkina M.A., Rasulova M.A., Zolotov S.V. Species of the genus Lathyrus L. from N.I. Vavilov Institute (VIR) collection - the source of initial material for high-protein forage varieties breeding. Zernobobovye i Krupyanye Kultury = Legumes and Groat Crops. 2012;4:62-71. (in Russian)

Chavan U.D. Chemical and biochemical components of beach pea (Lathyrus maritimus L.). Canada Department of Biochemistry. Memorial University of New found land, 1998. http://research.library. mun.ca/id/eprint/1196.

Ivanter E.V., Korosov A.V. Introduction to Quantitative Biology. Petrozavodsk, 2003. (in Russian)

Konarev A.V., Shelenga T.V., Perchuk I.N., Blinova E.V., Loskutov I.G. Characteristic of oat diversity (genus Avena L.) from the collection of N.I. Vavilov All-Russia Research Institute of Plants - an initial material for oat fusarium resistance selection. Agrarnaya Rossiya = Agrarian Russia. 2015;5:2-10. (in Russian)

Loskutov I.G., Shelenga T.V., Konarev A.V., Shavarda A.L., Blinova E.V., Dzubenko N.I. The metabolomic approach to the comparative analysis of wild and cultivated species of oats (Avena L.). Russ. J. Genet: Appl. Res. 2017;7(5):501-508.

Mahmud J.A., Hasanuzzaman M., Nahar K., Rahman A., Hossain M.S., Fujita M. Maleic acid assisted improvement of metal chelation and antioxidant metabolism confers chromium tolerance in Brassica juncea. L. Ecotoxicol. Environ. Saf. 2017;144:216-226. DOI 10.1016 j.ecoenv.2017.06.010.

Pastor-Cavada E., Juan R., Pastor J.E., Alaiz M., Vioque J. Protein isolates from two Mediterranean legumes: Lathyrus clymenum and Lathyrus annuus. Chemical composition, functional properties and protein characterization. Food Chem. 2010;122:533-538. https:// DOI.org/10.1016/j.foodchem.2010.03.002.

Pavlova N.S. Study of the chemical composition of wild-growing fodder legumes in the Russian Far East. Biologicheskiye Issledovaniya na Gornotayezhnoy Stantsii = Biological Research at the Mountain Reservoir Station. 2001;7:78-97. (in Russian)

Plant Resources of the USSR. Flowering Plants: Chemical Composition and Use. Vol. 3. Families Hydrangeaceae-Haloragaceae. Leningrad, 1987. (in Russian)

Plant Resources of the USSR. Flowering Plants: Composition and Biological Activity. Vol. 3. Families of Fabaceae-Apiaceae. St. Petersburg, 2010. (in Russian)

Popov V.D., Valge A.M., Sukhoparov A.I., Kovalev V.A. Influence of weather conditions on the quality of grass fodder. Vestnik Vserossiyskogo Nauchno-Issledovatelskogo Instituta Mekhanizatsii Zhivotnovodstva $=$ Proceedings of the All-Russia Research and Development Institute of Livestock Breeding Mechanization. 2016;3(23): 73-78. (in Russian)

Puzanskiy R.K., Shavarda A.L., Tarakhovskaya E.R., Shishova M.F. Analysis of metabolic profile of Chlamydomonas reinhardtii cultivated under autotrophic conditions. Appl. Biochem. Microbiol. 2015;51:83. https://DOI.org/10.1134/S0003683815010135.

Sheety P., Atallah M.T., Sheety K. Effects of UV treatment on the proline-linked pentose phosphate pathway for phenolics and L-DOPA synthesis in dark germinated Vicia faba. Process Biochem. 2002;37: 1285-1295.

Šibul F., Orčić D., Vasić M., Anačkov G., Nađpal J., Savić A., Mimica-Dukić N. Phenolic profile, antioxidant and anti-inflammatory potential of herband root extracts of seven selected legumes. Ind. Crop. Prod. 2016;83:641-653. http://dx.DOI.org/10.1016/j.indcrop. 2015.12.057.

Smolikova G.N., Shavarda A.L., Alekseichuk I.V., Chantseva V.V., Medvedev S.S. The metabolomic approach to the assessment of cultivar specificity of Brassica napus L. seeds. Russ. J. Genet: Appl. Res. 2016;6(1):78-83. 
Spanou C., Stagos D., Aligiannis N., Kouretas D. Influence of potent antioxidant leguminosae family plant extracts on growth and antioxidant defense system of Hep2 cancer cell line. J. Med. Food. 2010; 13(1):149-155. DOI 10.1089/jmf.2009.0058.

Vishnyakova M.A., Buravtseva T.A., Bulyntsev S.V., Burlyaeva M.O., Semenova E.V., Seferova I.V., Aleksandrova T.G., Jankov I.I., Egorova G.P., Gerasimova T.V., Drugova E.V. The VIR Collection of the Genetic Resources of Grain Legumes: Replenishment, Preservation, and Study Guidelines. St. Petersburg: VIR, 2010. (in Russian)

Yao S.Z., Chen P., Yang X.Y., Fung Y.S., Si S.H. Herbal organic acids. In: Deyl Z., Miksik I., Tagliaro F., Tesarova E. (Eds.). Advanced
Chromatographic and Electromigration Methods in BioSciences. J. Chromatogr. Library Series. 1998;60:344-370.

Zaichikova S.G. Effect of extracts from various Lathyrus species on the phagocytic and antibacterial activity of human neutrophils. Khimiko-Farmatsevticheskiy Zhurnal = Journal of Pharmaceutical Chemistry. 2002a;36(3):144-145. (in Russian)

Zaichikova S.G. Effect of extracts from various Lathyrus species on human B-cell differentiation and tumor growth. Khimiko-Farmatcevticheskiy Zhurnal = Journal of Pharmaceutical Chemistry. 20026; 36(4):30-31. (in Russian)

Zaichikova S.G., Samylina I.A., Burlyaeva M.O. Protein, amino acid and mineral composition of some species from Lathyrus genus. Pharm. Chem. J. 2001;35(6):343-344.

ORCID ID

A.E. Solovyeva orcid.org/0000-0002-6201-4294

T.V. Shelenga orcid.org/0000-0003-3992-5353

A.L. Shavarda orcid.org/0000-0003-1778-2814

M.O. Burlyaeva orcid.org/0000-0002-3708-2594

Acknowledgements. This work was supported by State Budgeted Project 0662-2019-0002 for VIR.

Conflict of interest. The authors declare no conflict of interest.

Received March 26, 2019. Revised May 29, 2019. Accepted June 16, 2019. 